\title{
Soymilk Preservation Using Extracts Of Cloves (Syzygium Aromaticum Myrtaceae) And Guinea-Pepper (Xylopia Aethiopica Annonaceae).
}

\author{
${ }^{1}$ Kabiru, Y.A., ${ }^{2}$ Makun, H.A., ${ }^{3}$ Saidu, A.N., ${ }^{4}$ Muhammad, L.H., ${ }^{5}$ Nuntah, L.C \\ and ${ }^{6}$ Amoo, S.A. \\ ${ }^{1}$ Federal University of Technology, P. M. B. 65, \\ ${ }^{2,3,4,5,6}$ Department of Biochemistry, Federal University of Technology, Minna, Nigeria
}

\begin{abstract}
The significance of preservatives in food preparations lies in their ability to inhibit or retard the growth of microorganisms which in turn reduces their deteriorative effects on food. The preservative effects of varying concentrations $(1 \%, 3 \%, 5 \% \mathrm{v} / \mathrm{v})$ of extracts of cloves (Syzygium aromaticum myrtaceae), guineapepper (Xylopia aethiopica annonaceae) and a combination of the two extracts on soymilk were studied in both shelfed and refrigerated samples. The $\mathrm{pH}$, protein and fat contents, and microbial load were used as parameters for determining the stability of the milk. The $\mathrm{pH}$ values for clove extract-treated soymilk samples on shelf showed increased level of acidity (5.16 \pm 0.13$)$ compared to treated-refrigerated samples $(6.62 \pm 0.03)$, while the protein contents decreased more with storage time and these were concentration dependent. The fat contents of the treated samples especially those treated with a combination of extracts were significantly higher $(P<0.05)$ than the untreated soymilk samples. Reduction in total microbial count was more pronounced in samples treated with clove extract $\left(1.92 \times 10^{5}\right)$ than those treated with guinea pepper extract $\left(2.70 \times 10^{5}\right)$ and the controls. The cloves-guinea pepper extract combination demonstrated the best preservative effect than the single extracts in terms of nutrient content but the antimicrobial activity of the clove extract at 3\% was significantly higher $(P<0.05)$ than those of guinea-pepper and the combination. The use of cloves as a preservative increased shelf life of soymilk by 2 on shelf and 8 days in the refrigerator, guinea pepper extended shelf life by 1 day on shelf and 6 days in refrigerator while combination of the extracts maintained a longer shelf life of 12 days in the refrigerator and 2 days on the shelf. The result of the study shows that a combination of the extracts is a better preservative of soymilk than the single extracts.
\end{abstract}

Keywords: Soymilk, Syzygium aromaticum myrtaceae, Xylopia aethiopica annonaceae, Preservative, Microbial

\section{Introduction}

The importance of protein in the diet of growing children and its continuous supply is very vital in Africa where the occurrence of protein energy malnutrition (PEM) is very rampant. Soybean, a highly proteinous seed has been identified over the years as a cheap and readily available source of protein that could be exploited to supply much of the needed nutrient. In developing countries and indeed in tropical regions of sub-saharan Africa (except East Africa), the production of milk and milk products are limited, scarce and expensive (Fashakun and Unokiwedi, 1992). Milk is an excellent source of nutrients such as vitamins, amino acid, fats, minerals, proteins and sugar, making it an excellent medium for microbial proliferation (Akinyele et al, 1999). Soybean seeds contains by weight approximately $32 \%$ carbohydrate, $20 \%$ fat, $5 \%$ minerals, $40 \%$ protein and 5\% vitamins (I.I.T.A.1990). It's lipid content is rich in polyunsaturated fatty acids like linoleic acid (52.3\%) and linolenic acid (7.2\%) (Lie and Prawirannegatae, 1974). These essential fatty acids reduce cholesterol content of blood thereby decreasing the possibilities of heart and blood vessel diseases in human beings (Morita et al, 1977).

Following the increasing awareness of the high nutrient value of soybean, there has been an increase in consumption and marketing of soybean products like soymilk, soy-cheese, soy-ogi, soy-cake, soy-flour and a host of others. Soymilk is the most popular of these products in Nigeria and efforts towards extending the shelf-life of soymilk is of utmost important (Gbodi et al, 2002).The extension of the shelf life of soybean products will help to save both time and labour spent in the preparation. The use of preservatives inhibiting and retarding the growth of microorganism responsible for the spoilage or decay of food substance needs to be addressed. Thus, the essence of natural preservatives over synthetic preservatives which is less costly and presents no toxicological problem and environmental hazards is of great of interest (Ihekoronye and Ngoody, 1985). Spices and condiments used as flavouring in foods also have antimicrobial properties. It's effectiveness is governed by its concentration. Garlic, ginger, cinnamon, rosemary, and cloves have shown to have bactericidal 
and antifungal properties. Their antimicrobial action is as a result of the phenolic compound content that binds to the microbial enzymes thus inhibiting microbial growth.

The antimicrobial activity of cloves against mycotoxigenic Aspergillus has been shown to be due to engenol (Bullerman et al., 1977). The essential oil fraction particularly in cloves (Syzygium aromaticum myrtaceae) has eugenol in high concentration approximately 95\%.The presence of this compound in cloves when added to baked food impacts flavour, aroma and functions as mold inhibitors (Paster et al., 1995). Although the antimicrobial activity of some spices and herbs has been documented, the amounts added to foods for flavour is not sufficient to completely inhibit microbial growth. This work was designed to determine the effect of varying concentrations of extracts and their combination on microbial growth and nutrient composition.

\section{MATERIALS}

Soybean seeds, cloves (syzygium aromaticum myrtaceae) Guinea pepper (xylopia aethiopica annonaceae) were purchased from Minna central market, Niger State, Nigeria.

\section{Methods}

\section{Preparation of Water Extracts of Guinea pepper and Cloves}

The fruit of guinea pepper and cloves were sun dried and ground into powder. $600 \mathrm{ml}$ of distilled water was added to $100 \mathrm{gm}$ each of powdered cloves, guinea pepper and blended. The mixture was allowed to stand for 30 minutes and was filtered using muslin cloth with the filtrate collected in a conical flask and stored.

\section{Preparation of Soy-Milk Samples}

The traditional Hausa method described by Gbodi et al., (2002) was adopted for the preparation of the soymilk. Soybean was thoroughly sieved to remove any possible stones and discoloured beans. 100gm of soybean was weighed and soaked in water for 30 minutes. The beans were dehusked and immediately blended with $250 \mathrm{ml}$ of distilled water. After blending, another $250 \mathrm{ml}$ of distilled water was added and sieved using muslin cloth with the filtrate collected in a beaker. $4 \mathrm{gm}$ of granulated sugar was then added to $100 \mathrm{ml}$ of the filtered soy-milk, 3(three) batches of four flasks each containing $100 \mathrm{ml}$ of filtered soymilk was prepared.

To each batch of four flasks of soymilk, varying concentration of aqueous extract of cloves, guinea pepper and clove-guinea pepper mixture were added. Extracts in concentrations of 1\%,3\%, and 5\%v/v were used to treat three batches of soymilk separately while the fourth batch was untreated serving as control. The treated and untreated samples were then grouped into 2 batches. A batch was boiled for 15 minutes while the other was pasteurized for 30 minutes at temperatures between $69-70^{\circ} \mathrm{C}$ in a controlled water bath.

\section{pH Determination}

The $\mathrm{pH}$ values of samples were determined using a $\mathrm{pH}$ meter (Crison micropH 2000)

\section{Fat Content Determination}

The determination of the fat content of treated and untreated soymilk samples were carried out using Werner Schmid method as described by Bassir (1978). The samples were mixed with concentrated $\mathrm{HCl}$ acid and heated in the steam bath until the mixture became dark brown. Ether was used to extract the fat in the bath. The weight of the remaining fat was taken and the fat content calculated on percentage basis.

\section{Protein Content Determination}

Biuret method as outlined by Stroev and Markarova (1989) was used in the determination of the protein content. A standard calibration curve was plotted using Bovine Serum Albumin (BSA) as standard protein and absorbance read at a wavelength of $540 \mathrm{~nm}$.

\section{Microbial Analysis / Microbiology}

Total microbial count was determined to assess the number of microbial cells and the effects of the different extracts on the microorganism. $1 \mathrm{ml}$ of each soymilk sample was dissolved in $9 \mathrm{ml}$ distilled water, after which serial dilutions were carried out (for both initial preparation and after spoilage) aseptically as described by Fawole and Oso (1988). 0.1 $\mathrm{ml}$ of each sample after serial dilution was plated out in duplicates on plate count nutrient agar (NA) plates for bacterial isolation and incubated at $37^{\circ} \mathrm{C}$ for 24 hours. Fungal counts were carried out using potato dextrose agar (PDA) and incubated at $28^{\circ} \mathrm{C}$ for 24 hours. Fungi were identified based on their appearance, texture, colour, rate of spreading and spore types under the microscope and matched with illustrations and characteristics in a standard laboratory fungi catalog.

Characterization of the bacterial isolates was carried out by the methods described by Cowan (1974), Ruickshank et al (1975) and Anisworth et al (1973). The morphology of the isolates were examined and characteristic colonies identified using the following microscopic techniques and biochemical tests: Gram stain reaction, catalase test, motility test to show presence of flagella, lactose fermentation test using Maccocky agar and gelatine hydrolysis test. Others include Hydrogen sulphide test using triple sugar iron (TSI) agar, Ejikman 
Soymilk Preservation Using Extracts Of Cloves (Syzygium Aromaticum Myrtaceae) And Guinea

test to indicate production of acid and gas, Voges-Proskauer test (VP) methyl red and spore stain test were carried out.

\section{pH Determination}

\section{Results}

The $\mathrm{pH}$ of the spice extracts in treated and untreated soymilk samples decreased with storage time indicating increased tendency towards acidity as shown in Table 1 for the various concentrations of extract as compared to the control. The samples treated with the highest concentration of cloves (5\%) had the highest decrease in $\mathrm{pH}(5.16 \pm 0.13)$ compared to other samples while the lowest decrease in $\mathrm{pH}$ values was recorded for guinea pepper extract - treated samples.

Table 1: pH values of treated and untreated soymilk samples

\begin{tabular}{|c|c|c|c|c|c|c|c|c|}
\hline \multirow[t]{2}{*}{$\begin{array}{l}\text { Soymilk } \\
\text { Samples }\end{array}$} & \multirow[t]{2}{*}{$\begin{array}{l}\text { Concentration } \\
\text { of } \\
\text { extract(\%v/v) }\end{array}$} & DAYS & $\mathrm{OF}$ & STORAGE & & & \multirow[t]{2}{*}{ Mean \pm SEM } & \multirow[t]{2}{*}{$\begin{array}{l}\text { Sample } \\
\text { Code }\end{array}$} \\
\hline & & 1 & 2 & 4 & 8 & 12 & & \\
\hline \multirow[t]{3}{*}{+ Cloves } & 1 & 6.30 & 6.27 & 6.23 & 6.00 & 5.96 & $6.15 \pm 0.07$ & PS \\
\hline & 3 & 6.88 & 5.80 & 5.71 & 5.67 & 5.56 & $5.92 \pm 0.24$ & PR \\
\hline & 5 & 5.66 & 5.20 & 5.05 & 4.98 & 4.90 & $5.16 \pm 0.13$ & US \\
\hline control & - & 6.71 & 6.69 & 6.60 & 6.57 & 6.52 & $6.62 \pm 0.03$ & UR \\
\hline \multirow{3}{*}{$\begin{array}{l}\text { +Guinea- } \\
\text { pepper }\end{array}$} & 1 & 6.48 & 6.38 & 6.23 & 6.19 & 6.12 & $6.28 \pm 0.06$ & PR \\
\hline & 3 & 6.51 & 6.47 & 6.41 & 6.38 & 6.29 & $6.41 \pm 0.03$ & UR \\
\hline & 5 & 6.57 & 6.18 & 6.09 & 5.98 & 5.80 & $6.12 \pm 0.12$ & US \\
\hline control & - & 6.61 & 6.50 & 6.41 & 6.30 & 6.12 & $6.39 \pm 0.08$ & PS \\
\hline \multirow{3}{*}{$\begin{array}{l}\text { +Clove- } \\
\text { guinea } \\
\text { pepper }\end{array}$} & 1 & 6.34 & 6.20 & 6.11 & 6.02 & 5.96 & $6.13 \pm 0.06$ & PS \\
\hline & 3 & 6.18 & 6.09 & 6.00 & 5.92 & 5.82 & $6.00 \pm 0.06$ & PR \\
\hline & 5 & 6.09 & 5.99 & 5.90 & 5.79 & 5.65 & $5.88 \pm 0.07$ & US \\
\hline control & - & 6.71 & 6.69 & 6.60 & 6.58 & 6.52 & $6.62 \pm 0.03$ & UR \\
\hline
\end{tabular}

\section{Fat content}

The effect of the different spice extract on the fat content of soymilk was determined after 24 hours of storage and is shown on Figure 1 and Table 2. The clove-guinea pepper combination produced the highest increase in percentage fat content of soymilk than those of individual spice extracts.

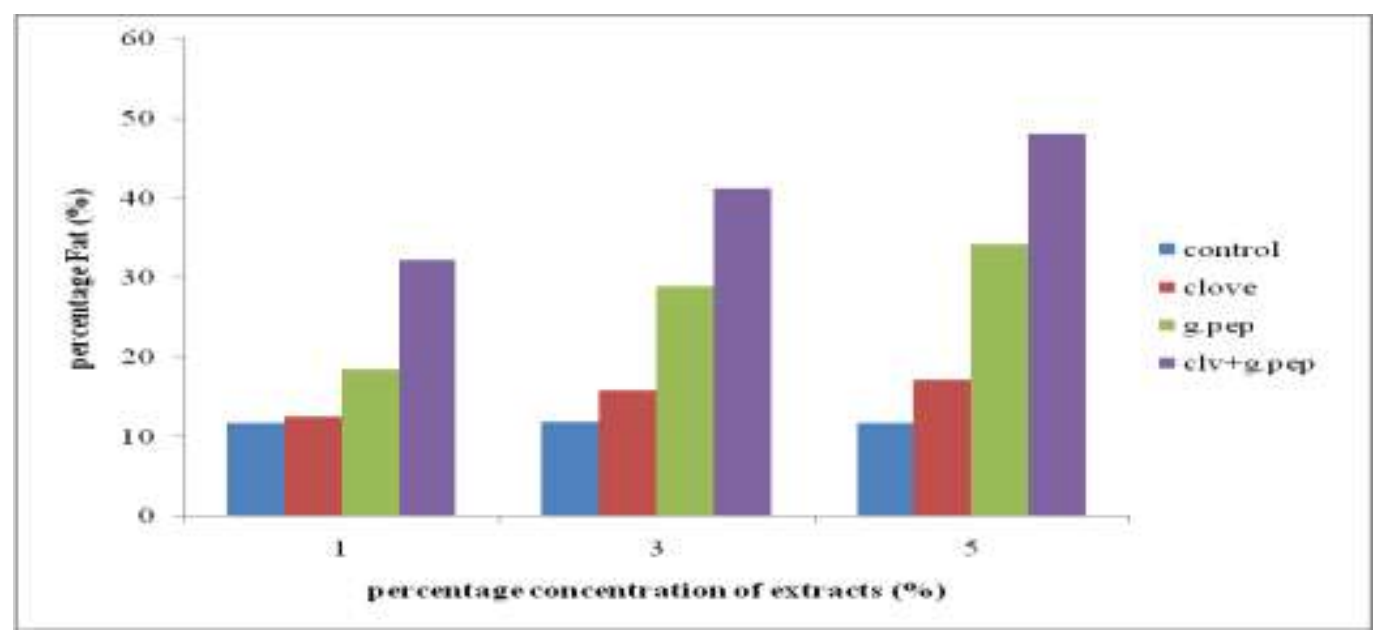

Figure 1 Effect of Spice extract on Fat content of Soymilk after 24 hours

NOTE: g.pep means guinea-pepper Clv+g.pep means clove+guinea-pepper combination 
Soymilk Preservation Using Extracts Of Cloves (Syzygium Aromaticum Myrtaceae) And Guinea

\begin{tabular}{lccl}
\hline \multicolumn{2}{l}{ Table 2: Fat content of treated and untreated soymilk samples after 24 hours } \\
\cline { 2 - 4 } Soymilk & $\begin{array}{c}\text { Concentration } \\
\text { of extract }(\% \text { v/v) }\end{array}$ & Fat & Sample \\
Samples & 1 & 12.60 & Code \\
\hline +Cloves & 3 & 15.90 & PR \\
& 5 & 17.20 & US \\
& - & 11.80 & UR \\
\hline control & 1 & 18.50 & PR \\
\hline +Guinea-pepper & 3 & 29.00 & UR \\
& 5 & 34.20 & US \\
& - & 11.95 & PS \\
control & 1 & 32.20 & PS \\
+Clove-guinea pepper & 3 & 41.20 & PR \\
& 5 & 48.10 & US \\
& - & 11.80 & UR \\
\hline
\end{tabular}

PS - Pasteurized soymilk on shelf

PR - Pasteurized soymilk refrigerated

US - Unpasteurized but boiled soymilk on shelf

UR - Unpasteurized but boiled soymilk on shelf refrigerated

\section{Protein Content}

The protein content in treated soymilk samples (Table 2) showed a decrease with storage time for all concentrations of extracts used when compared to the control. There was no significant $(\mathrm{P}>0.05)$ difference between clove and clove-guinea-pepper extract, but a significant $(\mathrm{P}<0.05)$ difference was observed for guineapepper when compared to control. However refrigerated samples had the least decrease in protein content than samples on shelf when compared and this decrease tended to reduce the nutritive value of the milk with respect to storage time.

Table 3: Protein concentration of treated and untreated samples of Soybean milk

\begin{tabular}{|c|c|c|c|c|c|c|c|c|}
\hline $\begin{array}{l}\text { Soymilk } \\
\text { Samples }\end{array}$ & $\begin{array}{c}\text { Concentration } \\
\text { of } \\
\text { extract }(\% \mathrm{v} / \mathrm{v})\end{array}$ & 1 & $\begin{array}{c}\text { DAYS } \\
2\end{array}$ & $\begin{array}{c}\text { OF } \\
4\end{array}$ & $\begin{array}{c}\text { STORAGE } \\
8\end{array}$ & 12 & Mean \pm SEM & $\begin{array}{c}\text { Sample } \\
\text { Code }\end{array}$ \\
\hline \multirow[t]{3}{*}{ +Cloves } & 1 & 22.95 & 22.15 & 22.00 & 21.75 & 21.50 & $22.07 \pm 0.24$ & PS \\
\hline & 3 & 22.70 & 22.20 & 22.00 & 21.90 & 21.70 & $22.10 \pm 0.17$ & PR \\
\hline & 5 & 22.50 & 20.50 & 19.50 & 15.50 & 11.50 & $17.90 \pm 1.96$ & US \\
\hline Control & - & 24.50 & 24.00 & 23.45 & 23.15 & 22.90 & $23.60 \pm 0.29$ & UR \\
\hline \multirow{3}{*}{$\begin{array}{l}\text { +Guinea- } \\
\text { pepper }\end{array}$} & 1 & 23.95 & 23.50 & 23.15 & 22.95 & 22.50 & $23.21 \pm 0.24$ & PR \\
\hline & 3 & 23.60 & 23.10 & 22.85 & 22.50 & 22.00 & $22.81 \pm 0.27$ & UR \\
\hline & 5 & 23.50 & 23.00 & 22.45 & 22.15 & 21.90 & $22.60 \pm 0.40$ & US \\
\hline control & - & 24.50 & 23.90 & 23.15 & 22.95 & 22.15 & $23.44 \pm 0.18$ & PS \\
\hline \multirow{3}{*}{$\begin{array}{l}\text { +Clove- } \\
\text { guinea } \\
\text { pepper }\end{array}$} & 1 & 22.50 & 21.50 & 20.95 & 20.00 & 19.17 & $20.82 \pm 0.58$ & PS \\
\hline & 3 & 22.00 & 21.50 & 21.00 & 20.00 & 19.25 & $20.73 \pm 0.50$ & PR \\
\hline & 5 & 21.50 & 21.00 & 20.95 & 20.00 & 19.15 & $20.54 \pm 0.41$ & US \\
\hline control & - & 24.50 & 24.00 & 23.45 & 23.15 & 22.90 & $23.60 \pm 0.29$ & UR \\
\hline
\end{tabular}

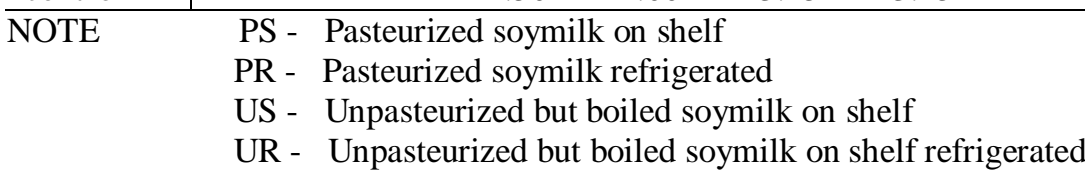

\section{Total Microbial Count}

During the storage period, there was significant bacterial and fungal growth observed in both the control and treated soymilk samples as shown in (Tables 3 and 4) respectively, but the counts were lower compared to the control. The clove-guinea pepper combination significantly $(\mathrm{P}<0.05)$ reduced microbial growth than the single extracts. The result also showed that the mean bacterial and fungal count for treated and untreated refrigerated soymilk samples were lower than values for samples on shelf. 
Soymilk Preservation Using Extracts Of Cloves (Syzygium Aromaticum Myrtaceae) And Guinea

Table 4: Bacteria total plate counts for treated and untreated soymilk samples $\left(\times 10^{5}\right)$

\begin{tabular}{l|llllllll}
\hline $\begin{array}{l}\text { Soymilk } \\
\text { Samples }\end{array}$ & $\begin{array}{l}\text { Concentration } \\
\text { of } \\
\text { extract(\%v/v) }\end{array}$ & 1 & $\begin{array}{c}\text { DAYS } \\
2\end{array}$ & $\begin{array}{l}\text { OF } \\
4\end{array}$ & $\begin{array}{l}\text { STORAGE } \\
8\end{array}$ & 12 & $\begin{array}{l}\text { Mean } \pm \text { SEM } \\
(\mathrm{x} \mathrm{10})\end{array}$ & $\begin{array}{l}\text { Sample } \\
\text { Code }\end{array}$ \\
\hline +Cloves & 1 & 0.2 & 2.1 & 2.8 & 3.9 & 5.4 & $2.88 \pm 0.87$ & PS \\
& 3 & 0.6 & 1.0 & 1.9 & 2.3 & 3.8 & $1.92 \pm 0.55$ & PR \\
& 5 & 0.1 & 1.7 & 2.1 & 3.2 & 4.0 & $2.22 \pm 0.67$ & US \\
control & - & 0.7 & 2.3 & 3.3 & 6.5 & 11.0 & $4.76 \pm 1.82$ & UR \\
\hline +Guinea- & 1 & 0.1 & 2.3 & 3.0 & 4.7 & 6.2 & $3.26 \pm 1.04$ & PR \\
pepper & & & & & & & & \\
& 3 & 0.2 & 1.8 & 2.8 & 3.2 & 5.5 & $2.70 \pm 0.87$ & UR \\
& 5 & 0.5 & 2.5 & 3.1 & 4.5 & 6.9 & $3.50 \pm 1.06$ & US \\
control & - & 1.2 & 3.2 & 4.6 & 6.9 & 13.5 & $5.88 \pm 2.11$ & PS \\
\hline +Clove- & 1 & 0.1 & 3.1 & 4.0 & 4.7 & 5.2 & $3.42 \pm 0.90$ & PS \\
guinea & & & & & & & & \\
pepper & & & & & & & & \\
& 3 & 0.1 & 1.9 & 2.2 & 3.3 & 4.0 & $2.30 \pm 0.66$ & PR \\
& 5 & 0.6 & 3.0 & 3.8 & 4.0 & 4.4 & $3.16 \pm 0.67$ & US \\
control & - & 0.7 & 2.2 & 3.3 & 6.5 & 11.0 & $4.74 \pm 1.83$ & UR \\
\hline
\end{tabular}

NOTE PS - Pasteurized soymilk on shelf

PR - Pasteurized soymilk refrigerated

US - Unpasteurized but boiled soymilk on shelf

UR - Unpasteurized but boiled soymilk on shelf refrigerated

Table 5: Fungal count for treated and untreated soymilk samples $\left(\mathbf{x ~ 1 0}^{\mathbf{5}}\right)$

\begin{tabular}{llccccccl}
\hline $\begin{array}{l}\text { Soymilk } \\
\text { Samples }\end{array}$ & $\begin{array}{l}\text { Concentration } \\
\text { of extract(\%v/v) }\end{array}$ & 1 & $\begin{array}{c}\text { DAYS } \\
\text { S }\end{array}$ & $\begin{array}{l}\text { OF } \\
4\end{array}$ & $\begin{array}{c}\text { STORAGE } \\
8\end{array}$ & $\begin{array}{l}\text { Mean } \pm \text { SEM } \\
\left(\mathrm{x} 10^{5}\right)\end{array}$ & $\begin{array}{l}\text { Sample } \\
\text { Code }\end{array}$ \\
\hline+ Cloves & 1 & 4.5 & 5.2 & 9.1 & 13.6 & 15.0 & $9.48 \pm 2.13$ & PS \\
& 3 & 2.5 & 3.5 & 7.9 & 9.8 & 14.4 & $7.62 \pm 2.17$ & PR \\
& 5 & 1.0 & 1.8 & 3.9 & 11.5 & 14.0 & $6.44 \pm 2.65$ & US \\
control & - & 4.0 & 5.2 & 12.0 & 16.8 & 18.0 & $11.20 \pm 2.88$ & UR \\
\hline +Guinea- & 1 & 2.8 & 3.4 & 8.1 & 11.7 & 12.5 & $7.70 \pm 2.02$ & PR \\
pepper & & & & & & & & \\
& 3 & 2.2 & 3.0 & 6.1 & 10.5 & 15.4 & $7.44 \pm 2.47$ & UR \\
& 5 & 0.8 & 1.7 & 2.9 & 7.8 & 8.9 & $4.42 \pm 1.65$ & US \\
control & - & 6.0 & 9.5 & 15.5 & 18.6 & 19.8 & $13.88 \pm 2.66$ & PS \\
\hline+ Clove- & 1 & 1.3 & 2.5 & 6.2 & 10.0 & 11.5 & $6.30 \pm 2.00$ & PS \\
guinea & & & & & & & & \\
pepper & & & & & & & & \\
& 3 & 1.1 & 2.1 & 4.2 & 9.6 & 10.2 & $5.44 \pm 1.89$ & PR \\
& 5 & 1.3 & 1.9 & 3.2 & 5.2 & 11.5 & $4.62 \pm 1.85$ & US \\
control & - & 4.0 & 5.2 & 12.1 & 16.8 & 18.1 & $11.24 \pm 2.90$ & UR \\
\hline
\end{tabular}

NOTE PS - Pasteurized soymilk on shelf

PR - Pasteurized soymilk refrigerated

US - Unpasteurized but boiled soymilk on shelf

UR - Unpasteurized but boiled soymilk on shelf refrigerated

\section{Discussion}

The microbial contaminants isolated in this study are of great importance because of their pathogenic effects. The seven fungi isolated; Aspergillus niger, Aspergillus flavus, Mucors species, Rhizopus stolonnifer, Penicillium species, Microsporium canis and Candida species are important food spoilage microbes that have been reported to be involved in the deterioration of fruit, vegetables and various food products (Akano et al, 1985; Smith and Moss, 1985; Atanda et al., 1990). The isolated and identified bacteria include Bacillus cereus, Staphylococcus aureus, Staphylococcus epidermis, Micrococcus luteus, Bacillus polymyxa, Klebsiella antlantae, Escherichia coli, Klebsiella edwardsii and Enterobacter species. These bacteria species are also important food spoilage agents (Frazier and Westhoff, 1978). Some of these bacterial species like the Lactobacillus species are known to produce lactic acid during fermentation while Staphylococcus species and Escherichia coli elicit gastrointestinal disorder in man. Apart from the health problem, the presence of microorganisms in soymilk 
results in the deterioration of the product and subsequent utilization of the valuable nutrients such as fat, protein and minerals for its own metabolic activity. This might explain the decrease in protein content while the increase in fat in the treated samples can be attributed to the high percentage of oils in cloves and guinea-pepper and this was demonstrated in the high fat content of the combination-treated sample. The presence of bacteria and fungi in soymilk as revealed in this work may be due to unhygienic handling, processing and use of equipment without aseptic methods of production (Farouk, 1989).

In this study, preservation of soymilk samples using a combination of Cloves and Guinea-pepper which are natural spices was found to be a more effective than the single spices used against almost all of the food borne microbes thus indicating synergistic action of the two extracts. Cloves increased the shelf life of soymilk by 2 days on shelf and 8 days in the refrigerator while Guinea-pepper extended the shelf life by a day on shelf and 6 days in the refrigerator. Samples treated with a combination of clove- guinea pepper extract showed a 2 day increase on shelf and 12 days in the refrigerator. The inhibitory activity of these extracts may be attributed to the presence of several constituents mainly eugenol, eugenyl acetate, beta- caryophyllene, 2-heptanone (Chaieb et al., 2007b), acetyl- eugenol, alpha-humulene, methyl salicylate, iso-eugenol, methyl-eugenol (Yang et al., 2003). The main constituents of their essential oils are phenyl-propanoides such as carvacrol, thymol, eugenol and cinnamaldehyde (Chaieb et al., 2007a). Several studies have demonstrated potent antifungal (Arina and Iqbal, 2002; Giordani et al., 2004; Pawar and Thaker, 2006; Park et al., 2007), antiviral (Chaieb et al., 2007a) and antibacterial effects of clove (Cai \& Wu, 1996; Bae et al., 1998; Lopez et al., 2005; Li et al., 2005; Betoni et al., 2006; Fu et al., 2007). The modes of action by which microorganisms are inhibited by essential oils and their chemical compounds seem to involve different mechanisms. It has been hypothesized that the inhibition involves phenolic compounds, because these compounds sensitize the phospholipid bilayer of the microbial cytoplasmic membrane causing increased permeability, unavailability of vital intracellular constituents (Juven et al., 1994) and/or impairment of bacterial enzymes systems (Farag et al., 1989). The components with phenolic structure such as eugenol have been found to be highly active against the test microorganisms. Clove oil has 79.2\% eugenol (Ranasinghe et al., 2002). Members of this class are known to be either bactericidal or bacteriostatic agents, depending upon the concentration used (Pelczar et al., 1988, Dorman et al., 2000). The high activity of the extract may be further explained in terms of the alkyl substitution into the phenol nucleus, which is known to enhance the antimicrobial activity of phenols (Pelczar et al., 1988; Dorman et al., 2000; Campo et al., 2003).

Refrigeration, the commonest basic house hold preservation method involves storage of food items at low temperatures of between $0-4^{\circ} \mathrm{C}$. At this temperature, the survival and growth of most spoilage agents is inhibited. The inhibitory effect of refrigeration accounts for the lower total microbial counts and slows the deteriorative rate with minimal nutrient loss in refrigerated samples as compared to those on shelf.

The inability of the clove, guinea pepper and a combination of clove-guinea pepper extract to completely inhibit fungal and bacterial growth may be due to the low concentration of the extracts used, as high concentrations of plant extracts are required before antimicrobial properties are observed (Ritcher and Vore, 1989). Moreover it is observed that higher amounts of spices are necessary to inhibit microbial growth in food than in culture media (Shelef, 1983). However, large amounts of the spice extracts required for complete microbial inhibition would affect the organoleptic properties of the milk product.

\section{Conclusion}

This study confirms that the use of aqueous extracts of clove-guinea pepper in combination coupled with refrigeration can appreciably prolong the shelf life of soymilk. Hence, the extracts of these spices represent an alternative source of natural antimicrobial substances for use in food systems to prevent the growth of foodborne microorganisms and extend the shelf-life of the processed food.

\section{Acknowledgements}

This work was funded by a STEP-B grant to the Federal University of Technology, Minna, Nigeria.

\section{References}

[1] Arina, B. and Iqbal, A. (2002). In vitro fungitoxicity of the essential oil of Syzygium aromaticum. World J. Mocrobiol. Biotech. 18(4): 317-319.

[2] Awan, J.A. and Okaka, J.C. (1985). Elements of food spoilage and preservation. Second edition;

[3] Akinyele, S.J., Fawole, M.O. and Akinyosoye, E.A. (1999). Microorganisms associated with fresh cow milk "wara" and "nono", two local milk products by Fulani woman in IIorin, Kwara state, Nigeria. Nigerian Food Journal 17; 10-15.

[4] Bae, E.A., M.J. Han, N.J. Kim and D.H. Kim. (1998). Anti-Helicobacter pylori activity of herbal medicines. Biol. Pharm. Bull., 21(9): 990-992.

[5] Bassir, O. (1987). Handbook of Practical Biochemistry, University of Ibadan Press p.87.

[6] Betoni, J.E., R.P. Mantovani, L.N. Barbosa, L.C. De-Stasi and F.A. Junior. 2006. Synergism between plant extract and antimicrobial drugs used on Staphylococcus diseases. Mem. Inst. Oswaldo Cruz., 101(4): 387-390

[7] Bolaji, P.T. (1987) In; improving the technologies of local beverages processing such as Kunun Zaki, turadanono, Burukutu/pilo and soyabean milk.Nigerian Institutes for Science and Technology Workshop . 
[8] Bullerman, L.B.; Lieu,F.Y. and Seier, S.A.(1977). Inhibition of growth and aflatoxin production by cinnamon and clove oils, annamic aldehyde and eugenol.Journal of food science 42:1107-1109,116.

[9] Cai, L. and C.D. Wu. (1996). Compounds from Syzygium aromaticum possessing growth inhibitory activity against oral pathogens. J. Nat. Prod., 59(10): 987-990.

[10] Chaieb, K., H. Hajlaoui, T. Zmantar, K.A.B. Nakbi, M. Rouabhia, K. Mahdouani and A. Bakhrouf.( 2007a). The chemical composition and biological activity of essential oil, Eugenia cryophyllata (Syzygium aromaticum L. Myrtaceae): a short review. Phytother Res., 21(6): 501-506.

[11] Chaieb, K., T. Zmantar, R. Ksouri, H. Hajlaoui, K. Mahdouani, C. Abdelly and A. Bakhrouf. 2007b. Antioxidant properties of essential oil of Eugenia caryophyllata and its antifungal activity against a large number of clinical Candida species. Mycosis, 50(5): 403-406.

[12] Dorman, H.J.D. and Deans, S.G. (2000). Antimicrobial agents from plants: antibacterial activity of plant volatile oils. Journal of Applied Microbiology 88: 308-316.

[13] Farouk,S.(1989).Preservative effects of benzoic acid and ascorbic acid in Kunu-zaki. Nigeria Food Journal 7: 13; 28-30.

[14] Frazier, W.C. and Westhoff, D.C. (1978). Food Microbiology $3^{\text {rd }}$ edition, McGraw Hill comp. New York. Pp $382-385$.

[15] Frazier, W.C. and Westhoff, D.C. (1998). Food Microbiology $4^{\text {rd }}$ edition, McGraw Hill publishers, UK pp $386-387$.

[16] Fu, Y., Y. Zu, L. Chen, X. Shi, Z. Wang, S. Sun and T. Efferth. 2007. Antimicrobial activity of clove and rosemary essential oils alone and in combination. Phytother. Res., 21(10): 989-994.

[17] Gbodi, T.A; Akanya, H.O.; Makun, H.A; Kabiru, Y.A. and Yakubu, Y.(2002). Preservation of soymilk using extract of ginger and garlic. Nigeria Journal of technological research 1:67-74.

[18] Giordani, R., P. Regli, J. Kaloustian, C. Mikail, L. Abou and H. Portugal. 2004. Antifungal effects of various oils against Candida albicans. Potentiation of antifungal action of amphotericin B by essential oil from Thymus vulgaris. Phytother. Res., 18(12): $990-$ 995 .

[19] International Institute of Tropical Agriculture (IITA) (1990). Soyabean for good health, how to grow and use soyabean in Nigeria. Paper presented at workshop, NSPRI pp 22.

[20] Ihekoronye, A. And Ngoody, P.O.(1985). Integrated food science and technology for the tropics. Mac publisher London pp 364373.

[21] Juven, B. J.; Kanner, J.; Sched, F. and Weisslowicz, H. (1994). Factors that interact with the antibacterial of thyme essential oil and its active constituents. Journal of Applied Microbiology, 76: 626-631

[22] Li, Y., C. Xu, Q. Zhang, J.Y. Liu and R.X. Tan. (2005). In vitro anti-Helicobacter pylori action of 30 Chinese herbal medicines used to treat ulcer diseases. J. Ethnopharmacol., 98(6): 329-333.

[23] Lie, G.H. and Prawirannegatea, D. (1974).Nutritive value of various legumes used in the Indonesian diet presented at first Asian workshop on grain legumes, Bogor, Indonesia pp 213-259.

[24] Lopez, P., C. Sanchez, R. Batlle and C. Nerin. 2005. Solid- and Vapor-phase antimicrobial activities of six essential oils: susceptibility of selected food borne bacterial and fungal strains. J. Agric. Food Chem., 53(17): 6939-6946

[25] Morita, T.; Akura, O. Kaori, T.; Michiyoshi, I.; Seli chi .k and Shubachi, K. (1997). Cholesterol lowering effects of soyabean, potato and rice protein depend on their low methionine content in rats fed with cholesterol- free petrified diet. Journal of American society for nutritional sciences. Pp 470-477.

[26] Nduka ,U. and Yakubu, I. (1990). Public health food and industrial microbiology. Pp 10-22.

[27] Park, M.J., K.S. Gwak, I. Yang, W.S. Choi, H.J. Jo, W.J. Chang, E.B. Jeung and I.G. Choi. 2007. Antifungal activities of the essential oils in Syzygium aromaticum (L.) Merr. Et Perry and Leptospermum betersonni Bailey and their constituents against various dermatiphytes. J. Microbiol., 45(5): 460-465.

[28] Pawar, V.C. and V.S. Thaker. 2006. In vitro efficacy of oils against Aspergillus niger. Mycosis, 49(4): 316-323

[29] Paster, N; Menasherov, M; Rawid, U; and Juvan, B.(1995).Antifungal activity of oregan and thyme essential oils applied as fumigants against fungi attacking stored grain. Journal of food protection. $\underline{58}$ 81-85.

[30] Pearson,D.; Egan, H.; Ronald, S.K. and sawyer, R (1981). Pearsons chemical analysis of food. $8^{\text {th }}$ edition Longman group Ltd New York pp 11-22.

[31] Pelczar, M.L.; Chan, E.C.S.; Krieg, N.R. (1988). Control of microorganisms, the control of microorganisms by physical agents. In: Microbiology, New York: Mc Graw-Hill International pp. 469-509.

[32] Ranasinghe, L.; Jayawardena, B. and Abeywickrama, K. (2002). Fungicidal activity of essential oils of Cinnamomum zeylanicum (L.) and Syzygium aromaticum (L.) Merr et L.M. Perry against crown rot and anthracnose pathogens isolated from banana Letters in Applied Microbiology 35: 208-211

[33] Ritcher, E.R. and Vore, L.A.(1989). Antimicrobial activities of banana puree. Journal of food microbiology. 6: 179-197.

[34] Sheief, L.A. (1983). Antimicrobial effects of spices. Journal of food safety 6: 29-44

[35] Shelef, L.A.; Jyothi, E.K. and Bulgarelli, M. (1984). Effect of sage on growth of enteropathogenic and spoilage bacteria in sage containing broths and foods. Journal of Food Science 737-740, 809.

[36] Stroev, E.A. and Makarova, V.G. (1989). Laboratory manual in biochemistry. MIR Publisher Company; Moscow pp 53-55. 